\begin{tabular}{lccc} 
& GOSPODARKA & SUROWCAMI & MINERALNYMI \\
\hline Tom 29 & 2013 & Zeszyt 4 \\
& & DOI 10.2478/gospo-2013-0040 &
\end{tabular}

\title{
The problem of developing prospective hard coal deposits from the point of view of social and environmental conflicts with the use of AHP method
}

\begin{abstract}
Introduction
In recent years, due to the revival in raw material markets, numerous socio-environmental conflicts have been reported in Poland and other European countries in relation to the opening up of new or previously abandoned mineral deposits. The problem concerns different mineral deposits which are mined using different methods and on a different scale, and it is one of the main threats to the country's raw material security. Very often it is the social acceptance of mineral exploitation in a given region that determines whether a mining entrepreneur will launch, abandon or shift the focus of an extraction project. Stakeholders in the mining sector include: local authorities, non-governmental organisations, the local community and/or individual citizens. The media also take an active part in the conflicts. The causes of such conflicts as well as the mechanisms behind them are complex (Sobczyk 2007; Badera 2010; Radwanek-Bąk, Nieć 2011; Poros M., Sobczyk W. 2013 and other publications). The difficulties could be overcome by implementing solutions that would be both satisfactory to all stakeholders and consistent with the idea of sustainable development. This requires a more detailed analysis and further activities in various fields, from developing regulations for the protection of mineral resources as part of spatial planning (Ramani,
\end{abstract}

* Ph.D.Sc., professor IGSMiE PAN, Mineral Energy and Economy Research Institute, Polish Academy of Sciences, Kraków, Poland; e-mail: jsobczyk@min-pan.krakow.pl

** Ph.D., Faculty of Earth Sciences, University of Silesia, Sosnowiec, Poland; e-mail: jaroslaw.badera@us.edu.pl 
Sweigard 1984; Jena 1992; Radwanek-Bąk 2007; Nieć 2008), investing in different types of eco-innovation (Hebestreit et al., ed. 2011; Niemczyk 2011) as well as performing activities related to public relations and corporate social responsibility (Cragg et al. 1995; Humphreys 2000; Byrska-Rapała 2008; Mossakowska, Wasilewski 2011), to developing direct methods for resolving particular conflicts and building a consensus through partnership between companies, local authorities and whole local communities (Esteves, Barclay 2011; Frączek 2011; Prno, Slocombe 2012).

Polish hard coal mining also faces this problem. As for operational mines, there are the methods and impacts of mining rather than the rationale behind it that is contested. There have also been protests over the opening up of single longwalls (the "Pokój" hard coal mine in Ruda Śląska, Nowy Bytom district) or larger extraction sites (the "Bielszowice" hard coal mine in Zabrze, reactivation of mining operations in the Pawłów district). Establishing completely new, i.e. apart from the existing ones, mining licence areas as well as reactivating the extraction of deposits which were abandoned due to the closing of a previously operating mine is a much bigger problem. These two situations should be treated separately to a certain extent; nonetheless, it has to be assumed that, in both cases, conflicts and protests are unavoidable. What remains unknown are the direct causes, the scale of and the major stakeholders (interveners) in such conflicts. The areas of Bzie-Dębina and Pawłowice (i.e. new deposits that are planned to be developed by the Jastrzębska Spółka Węglowa company), Dębieńsko (to be reopened by the NWR Karbonia company) or the area of the former Jan Kanty mine in Jaworzno (also to be reopened by HMS Niwka Coal Production Co. and other companies) can be used as case studies.

The question then arises whether one can predict anything in this respect and if it is possible to identify which of the specific deposits is relatively less contentious with regard to the surrounding natural environment, local community, infrastructure, etc. Determining the possible options would make it easier for public institutions to make optimal decisions and it would let mining companies minimise investment risk. Moreover, it would also provide objective arguments to the interested parties during negotiations.

\section{Characteristics of the analysed deposit areas}

Thirteen recognized hard coal deposits which are located in different parts of the Upper Silesian Coal Basin, i.e. within the Silesia and Małopolska Provinces, were selected for modelling research (Fig. 1). Exploitation of the deposits: Dębieńsko, Jan Kanty, Morcinek, Niwka-Modrzejów, Siersza and Żory was halted in the years 1996-2000 for economic reasons, and their technical infrastructure was partially or wholly shut down. However, large resources of hard coal still exist so, given the new economic situation, the deposits are again beginning to attract investors' interest. Since 2008 NWR Karbonia has been holding a mining licence for a larger part of the Dębieńsko deposit (the project of extending exploration to shallower coal seams triggered protests from some of the local inhabitants). 
The remaining seven deposits have not been developed yet. The area of Palowice with its undocumented resources which is adjacent to three of the above-mentioned deposits, was also taken into account.

Oświęcim-Polanka is one of two documented hard coal deposits which are the largest in the whole Upper Silesian Coal Basin. It covers almost the whole area of the town of Oświęcim. As for the way the land above the deposit is used, what is noteworthy is that a very large part of it is covered by water management areas (fish ponds with a total area of several hundred ha). Nearly the whole south-western part of the deposit is located within Natura 2000 sites, which mostly cover areas of the Soła and Skawa river valleys. Establishing a mining area for the whole deposit documented in this way seems out of the question if only because of the region's large area. Moreover, such type of land use, as described above, may undoubtedly encourage mobilisation of some of the stakeholders against mining operations. Therefore, in order to carry out a more in-depth analysis, an area called Polanka was separated from the Oświęcim-Polanka deposit to only cover the Polanka commune and some parts of the neighbouring communes (mostly arable land with rural buildings). While



Fig. 1. Location of the analysed deposits and their relative potential for socio-environmental conflict based on a multi-criteria analysis (AHP method)

Rys. 1. Lokalizacja analizowanych złóż oraz ich względna konfliktogenność określona na podstawie analizy wielokryterialnej (metoda AHP) 
delineating the area, the authors excluded the above-mentioned urban-industrial region of Oświęcim as well as the whole northern part of the deposit located within the Vistula river's meanders and the aforementioned Natura 2000 sites, which should considerably limit the possibility of conflict related to a prospective mining project. The separated Polanka area is another object of this analysis.

Altogether the research covered 15 separate areas. It is worth noting that all of the analysed deposits can only be extracted by the underground mining method because the coal seams there are situated deep underground. Currently, in Poland longwall mining is usually used where the roof is allowed to collapse. It is the most economical method but it also causes ground deformation and, consequently, different kinds of damage from mining.

\section{Risk factors}

Case studies (not only in the area of hard coal mining), their generalised analyses as well as theoretical deliberations will make it possible to identify the main factors behind a given conflict. Particular areas of interest for the mining industry may differ in the extent, i.e. rate and area of occurrence, of a given feature. In any case, however, one should analyse a basic set of possible factors at play. Initially, 12 out of many potential factors were selected which referred to various and relatively independent features, which then became criteria for further analysis based on the AHP model (Analytic Hierarchy Process).

\subsection{Spatial and demographic factors}

Area of the deposit. Assuming that factors which could be the source of conflict are equally distributed, the larger the area, the higher the probability of their occurrence.

Urbanisation level. This is the ratio of the build-up area to the area of the whole deposit. It refers both to areas covered by public utility services and industrial areas as well as to different kinds of buildings that are sensitive to ground deformation. If the deposits that are compared are roughly equally distributed, the growth of this indicator means that the potential for conflict also increases.

Population density. This parameter is expressed as the number of inhabitants per unit of area. The way it can influence the possibility of conflict is obvious (the higher the value of this parameter, the greater the probability of protests). It usually greatly varies also within a single documented area. When specifying the number of inhabitants, one should take into account the towns, cities and villages as well as town/city districts that are partially or mostly located within the documented area and also those which are adjacent to this area. Therefore, this parameter does not express the real population density of an area where a given deposit is located, but rather the number of stakeholders per unit of the deposit's area.

Net migration rate. In many cases it can be noticed that the interveners (individuals or groups of people) are migrants who have moved to a given place. Most of them left the large, 
industrial cities to move to the outskirts or to the country (it is interesting to note that there are also retired miners with their families among them). As they themselves often put it, they moved "to find peace and quiet", so they object to the opening of a mine in their vicinity in order to defend this idea. The net migration rate can indicate the absolute difference between the number of people coming to a given place and the number of those who are leaving it. Usually, however, the difference is calculated for 1000 inhabitants because only in this way can migration trends in differently populated places be compared. A higher net migration rate might mean that the inhabitants are more likely to protest against mining operations.

\subsection{Economic factors}

Unemployment rate. It can be expressed as the ratio of the number of registered unemployed people to the total number of people who are professionally active or at working age. It is assumed that a higher unemployment rate will make the acceptance of a mining project, both on the part of the local community and local authorities, more likely.

Salary level. It can also be assumed that the higher the inhabitants' income, the less interested they will be in a planned mining project and the more likely to protest against it. It will be the opposite for low salaries, in which case also local authorities might be motivated by the prospect of raising the population's income.

Local government's income. The higher a commune's or town/city's own income, the less interested it will be in a new project and vice versa.

\subsection{Social factors}

The number of local government and auxiliary administrative units. Commune heads, mayors or city mayors are official bodies that give opinions, make agreements and issue decisions as part of the procedures related to spatial planning, evaluating the environmental impact and issuing mining licences. The bigger the number of such official bodies (local government units) in a given deposit area, the higher the likelihood that one of them will have an unfavourable attitude towards a mining project. Designated village areas as well as town/city districts or housing estates are so-called auxiliary administrative units of communes or towns/cities. Even though no legally binding decisions are made at this level, the commune heads, mayors and city mayors usually act in concert with the representatives of these units. Also, particular administrative units are closely related to electoral districts, which is where council members come from. What is more, designated village areas and town/city districts or housing estates are basic units where grassroots movements originate and where individual political careers begin. Therefore, again, a higher number of designated village areas, town/city districts and housing estates (which is strongly correlated with the number of local government units) may be a conflict-inducing factor. 
Local media activity. Both local and national mass media play a special and important role in such conflicts. As the process of disseminating information has been democratised and the media have retained their power to influence public opinion, the media's role seems to be continually growing. Therefore, the media (which shape public opinion or, at least, present information selectively) may take an active part in a conflict or even become another party to it. The probability of national or regional media taking part in such conflicts does not depend on the location. It can also be assumed that local media operate everywhere at the town/city or commune level (mostly the press and Internet portals). Designated village areas and town/city districts do not usually enjoy their own press titles. What can make particular areas different from the rest is the availability of Internet services, blogs and forums. It can be observed that, even in relatively small villages (with a population of approx. several hundred), one or two independent Internet portals are used which have several dozen visits a day. Such websites are very fast and very often act as an open-access forum for debate on a given topic. The websites' technical and formal level is quite good but their content can be of different quality. Given the above, it can be assumed that the number of such village- or housing estate-specific Internet websites is another factor which can raise the intensity of conflict.

The number of non-governmental organisations. The social activity of local communities is first of all reflected in the number of non-governmental organisations (NGOs) which operate in a given area (in particular inhabited places). The total number of such organisations obviously depends on the total number of inhabitants, but when it is expressed per 1000 inhabitants, there is no correlation between the values whatsoever. This means that the tendency to organise into activist groups which can act as a party to a conflict differs among the inhabitants of different places. As far as potential opposition to a mining company's plans is concerned, what is important is the number of local ecological organisations and how many enthusiasts a given town/city or region, etc. has. Also, the objective of some tourism organisations or associations for the development of a given town/city or village is to protect the environment or the local cultural heritage, etc. The number of such organisations is clearly correlated with the total number of NGOs in a given area, and thus with a general tendency for grassroots movements. It must be remembered that such non-governmental organisations can only be established during a conflict over a specific mining project, as was the case with, for example, Social Committee for the Protection of Pielgrzymowice or Social Committee for the Protection of Ruptawa and Cisówka (the area of Bzie-Dębina). Obviously, also national and even international organisations may express their protest against mining operations, but the probability of them taking part in such conflicts is the same for area.

\subsection{Environmental factors}

Landscape parks and Natura 2000 sites. The presence of nature conservation sites and features is undoubtedly one of the key factors that cause conflict as both non-governmental organisations and local authorities emphasise the necessity to protect 
可

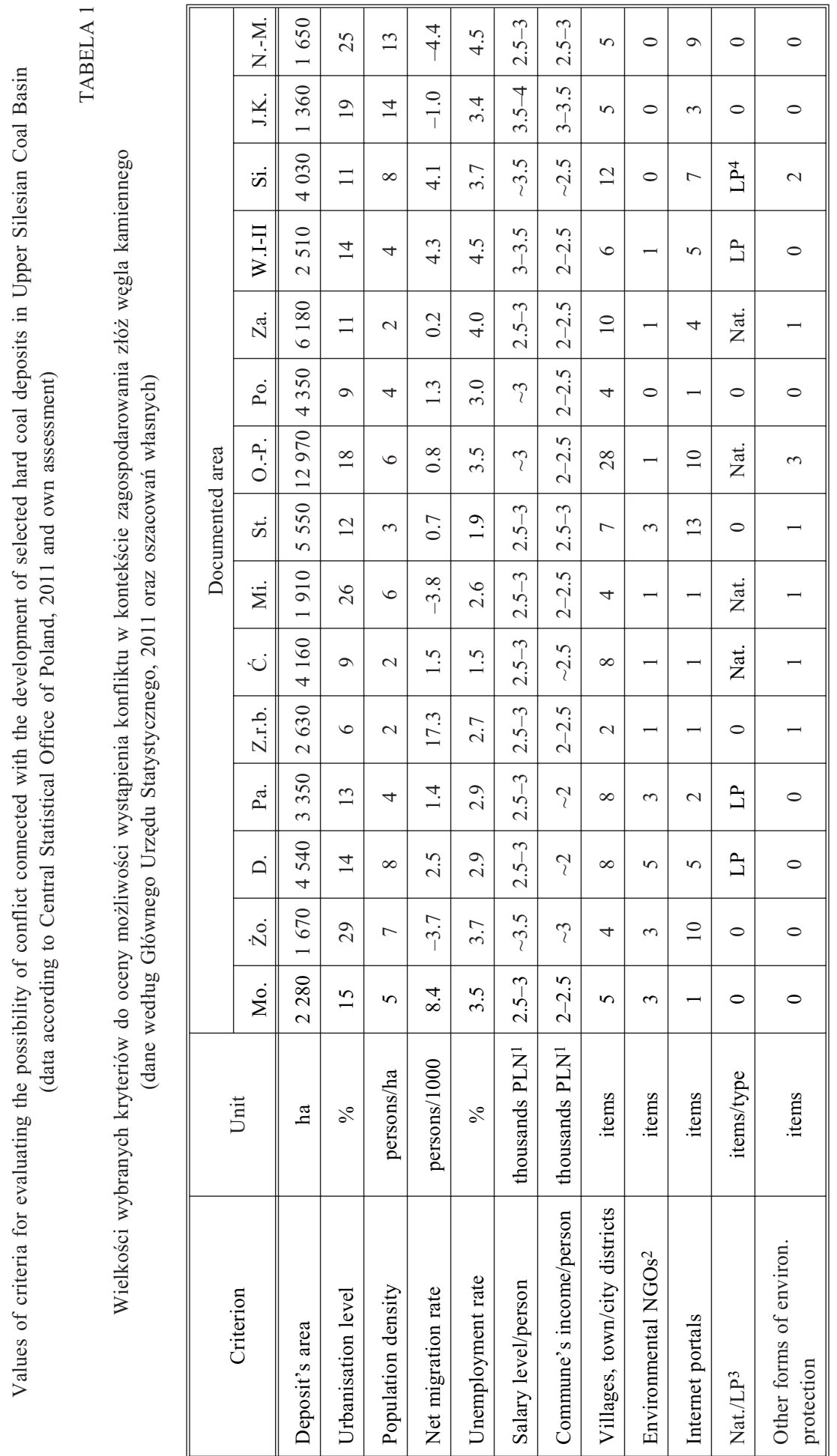

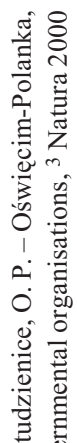
范主

กิ

荵

$\sum_{1}^{\infty} \frac{n}{0}$ 
the natural environment. It should also be noted that the argument about environmental protection is also very often used by local communities even though, in reality, the local inhabitants are more focused on the human habitat, and especially on the threat to its material aspects. Nevertheless, the environmental attributes of particular areas are obvious and what is debatable is the range and intensity of the impact of mining on protected sites. Apart from the national parks, the largest environmental features which also enjoy relatively strict protection measures are landscape parks and Natura 2000 sites. In this case the ratio of a protected site's area to the total area of a deposit can be a risk factor.

Other forms of environmental protection. Other forms of site and feature conservation, i.e. nature reserves, landscape protection areas, nature and landscape complexes, ecological sites, areas possibly designated as part of the CORINE programme, documentation sites (natural and man-made geological exposures) as well as natural monuments (trees, separate rocks and glacial erratics) are of additional importance (because of the scope and/or restrictiveness of protection measures). Table 1 summarises selected evaluation criteria for particular deposits.

\section{Multi-criteria analysis (AHP method)}

\subsection{Theoretical foundations of the AHP method}

Evaluating the possibility of conflict occurring in relation to the development of hard coal deposits is a complex issue because of the quantity and variety of factors (criteria) which influence the final evaluation as well as the nature of factors which can be both quantitative and qualitative. A systemic evaluation of the possibility of conflict requires the appropriate tool to be used which will take into account a large variety of factors, interdependencies between them as well as their impact on a given deposit. Therefore, a mathematical, multi-criteria decision-making method, namely the AHP (Analytic Hierarchy Process) was used to analyse the above-mentioned problem. The essence and uniqueness of this method is that it is based on a multi-criteria, hierarchical model (Saaty 1980). Examples of using the AHP or other multi-criteria methods to analyse problems connected with mining, and especially environmental and social ones, have so far been presented sporadically (Bascetin 2007; Esteves 2008; Sobczyk 2008; Sobczyk et al. 2011; Uberman, Ostrega 2008). A decision-making problem is solved by using the AHP in three main stages which constitute an integrated and logical whole.

Stage I - developing a hierarchical structure (or network) for a problem. At the first stage a multi-criteria problem is structured hierarchically. The elements of the structure are significant factors which have been identified and separated, and which will have an influence on the solution. A hierarchical structure is built in such a way that first a general problem is stated and then it is gradually broken down into details, i.e. it becomes decomposed into smaller and simpler components. 
Stage II - developing a hierarchy of factors: judgments (evaluations) and synthesis. At the next stage weights are calculated for factors at successive levels from row 1 to row $n$ and then checked for possible errors. For each factor in the hierarchy both local and global weights are computed. A local weight is connected to a given level whereas a global weight is derived by multiplying a local weight of an element at a given level with a global weight of an element from a higher level. At this stage matrix $A$ is obtained (of size $n \times n$, where $n$ is the number of elements at a given level) of pairwise comparisons of particular factors at a given level against the higher level (1). In the matrix comparisons $n(n-1) / 2 n(n-1) / 2$ are made pairwise.

$$
A=\left[a_{i j}\right]=\left[\begin{array}{cccc}
1 & a_{12} & \cdots & a_{1 n} \\
a_{21} & 1 & \cdots & a_{2 n} \\
\vdots & \vdots & \cdots & \vdots \\
a_{n 1} & a_{n 2} & \cdots & 1
\end{array}\right]
$$

Elements above the diagonal $a_{j i}=w_{i} / w_{j}$ (evaluation of the priority of element $i$ over element $j$ ) are the experts' judgments that were graded on a nine-point scale; the elements below the diagonal are reciprocals of the elements from above the diagonal $a_{j i}=1 / a_{j i}$.

In order to evaluate the elements' importance, an intensity of importance scale, as presented in Table 2, should be used.

TABLE 2

Scale of the importance of criteria and subcriteria (based on Saaty 1980)

TABELA 2

Skala ocen ważności kryteriów i subkryteriów (na podst. Saaty 1980)

\begin{tabular}{|c|l|}
\hline \hline Importance level & \multicolumn{1}{c|}{ Explanation } \\
\hline \hline 1 & Elements (features) are equally important \\
\hline 3 & Dominance of one element over another is small (minimal) \\
\hline 5 & Dominance of one element over another is average (significant) \\
\hline 7 & Dominance of one element over another is strong \\
\hline 9 & Dominance of one element over another is very strong (absolute) \\
\hline $2,4,6,8$ & Intermediate values between the odd values \\
\hline \hline
\end{tabular}

In the AHP method, determining the maximum eigenvalue $\lambda_{\max }$ for each matrix and the related eigenvector $w$, after creating a judgment matrix which illustrates a given problem, is the basis for determining priorities (weights).

One of the ways of determining eigenvector $w=\left(w_{i}, \ldots, w_{n}\right)$ is to normalise the columns of geometric means calculated for each row by using formula (2): 


$$
w_{i}=\frac{r_{i}}{\sum_{i=1}^{n} r_{i}}
$$

where:

$$
\begin{aligned}
& r_{i}=\left(\prod_{j=1}^{n} a_{i j}\right)^{1 / n} \\
& r_{i}-\text { is the geometric mean, } \\
& a_{i j}-\text { is a matrix element, } \\
& n-\text { is the matrix size, } \\
& \text { for } i, j=1,2, \ldots, n
\end{aligned}
$$

The maximum eigenvalue of matrix $\lambda_{\max }$ can be computed by using formula (3):

$$
\lambda_{\max }=\frac{1}{n} \sum_{i=1}^{n} \lambda_{i}
$$

where:

$$
\begin{gathered}
\lambda_{i}=\frac{\sum_{j=1}^{n} a_{i j} \cdot w_{i}}{w_{i}}, \\
\lambda_{i}-\text { is the eigenvalue of the matrix. }
\end{gathered}
$$

In order to assess errors or inconsistencies in the opinions of an expert or experts, the maximum eigenvalue of judgment matrix $\lambda_{\max }$ is used. The larger the difference between value $\lambda_{\max }$ and matrix size $n$, the bigger the errors that can be made when using this method. Eigenvalue $\lambda_{\max }$ has its corresponding eigenvector ( $\left.w\right)$, all components of which are bigger than zero and that is why it is used as the vector of priorities (weights). AHP allows for errors but only to a certain degree. The Consistency Index (CI) is used to identify errors. It is calculated by using the formula (4):

$$
C I=\frac{\lambda_{\max }-n}{n-1} \leq 0.10
$$

where:

$n \quad-\quad$ is the matrix size,

$\lambda_{\max }-$ is the maximum eigenvalue of the matrix.

When the Consistency Index $C I>0.1$, the valuation should be repeated in a given matrix. 
Stage III - yielding and evaluating global priorities. At the final stage priorities (weights) are determined for particular alternative solutions, which are then ranked and evaluated.

As a result, the following vector is obtained:

$$
C[1, k]^{T}=\prod_{i=2}^{k} B_{i}=B_{i} \cdot B_{k-1} \ldots B_{2}
$$

where:

$C[\mathrm{I}, k]$ - is a resultant vector of priorities (weights) which are assigned to the elements of hierarchy level $k$ (alternative solutions) in relation to the goal, i.e. the first level,

$B_{i} \quad-\quad$ is an $i$ level matrix the columns of which are vectors of this level's priorities in relation to the elements of level $i-1$.

The resultant vector's components are ranked according to their value in order to establish the importance of the analysed elements which, in this case, are alternatives (deposits) undergoing evaluation. The values of priorities constitute a basis for putting a set of alternatives in order (ranking of alternatives) and indicating the alternative which has the highest priority. The local and global weights that are obtained for particular elements at a given level of the model provide a basis for analysing their contribution to the final result.

\subsection{Hierarchical model for evaluating the possibility of conflict in the context of developing of hard coal deposits}

The evaluation of the possibility of conflict occurring in relation to the development of hard coal deposits depends, to a large extent, on the appropriate choice of features (factors) that have an impact on the above-mentioned problem. This article focuses on a content-based selection of factors that was carried out by experts. The criteria were selected in a way which ensures that they describe the analysed problem comprehensively. Therefore, both qualitative and quantitative criteria were used.

Based on selected factors, a hierarchical model for evaluating potential conflicts related to the development of hard coal deposits was built. Fig. 2 illustrates the task structure. Level 1 of the model consists of one element, i.e. the goal of the task which is to evaluate the possibility of conflict related to developing hard coal deposits. At level 2 general criteria (groups of criteria) were adopted ( $c f$. Chapter 2). The main groups of criteria that are relevant to the goal are:

- spatial and demographic factors,

- economic factors,

- social factors,

— environmental factors. 
16

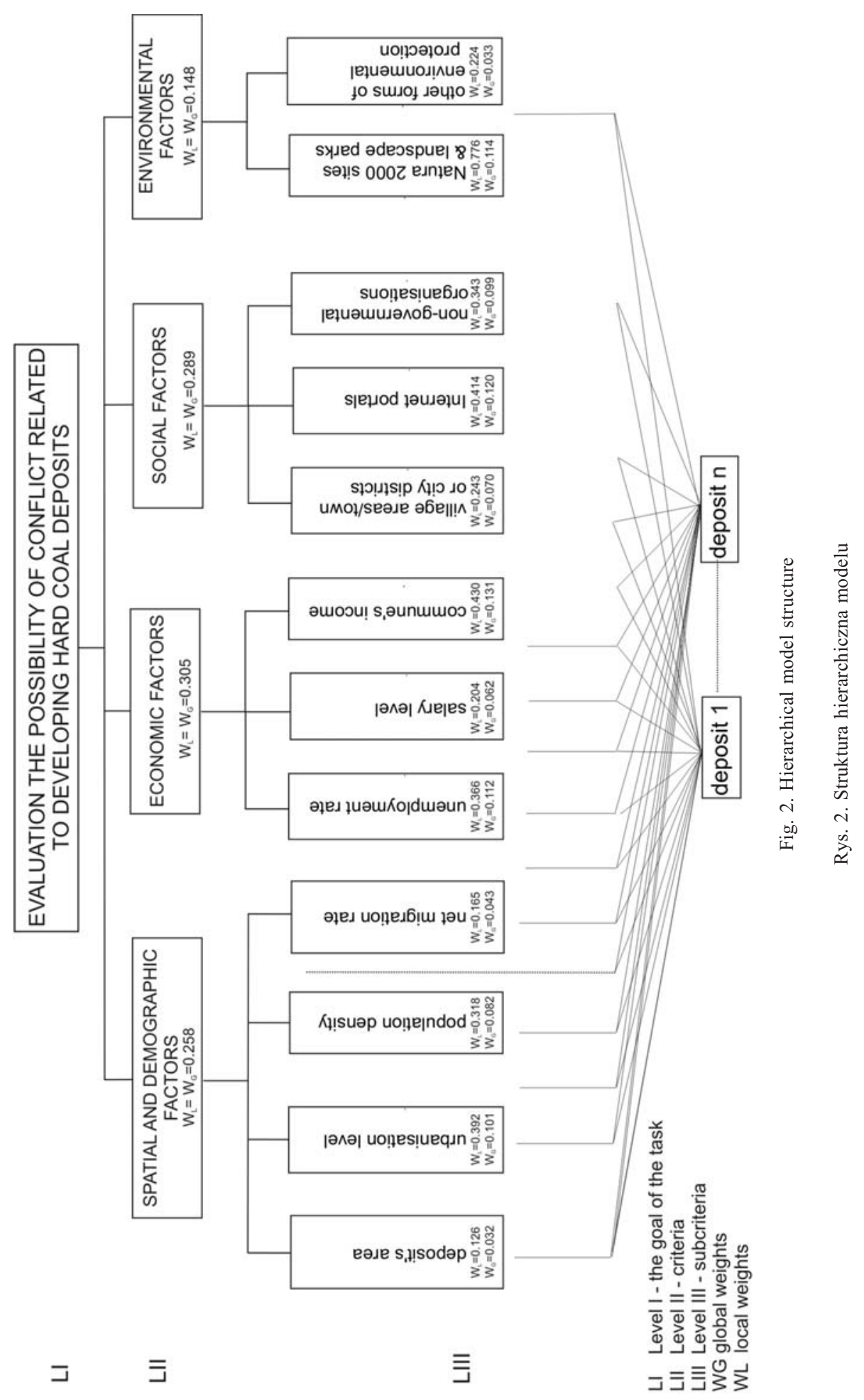


At the next, i.e. $3^{\text {rd }}$ level of the model, the so-called subcriteria were identified which describe each of the main criteria in more detail.

In the group of spatial and demographic factors, four most significant subcriteria were specified (cf. Chapter 2.1):

- deposit's area (ha),

- urbanisation level (\%),

— population density (person/ha),

- net migration rate (person/1000).

In the group of economic factors the most important characteristics of the areas' economic potential were identified ( $c f$. Chapter 2.2), and thus three basic quality subcriteria were selected:

- unemployment rate (\%),

— salary level (thousand PLN/person; PLN - Polish zloty),

- commune's income (thousand PLN/person).

The group of social factors encompasses the following ( $c f$. Chapter 2.3):

— designated village areas/town or city districts (items),

- Internet portals (items),

- non-governmental organisations (NGO)(items).

The group of environmental factors refers to those aspects of conflict which are related to the environment ( $c f$. Chapter 2.4). These are:

- Natura 2000 sites \& landscape parks (type, relative participation in a deposit area),

- other forms of environmental protection (items).

The analysis of the possibility of conflict in relation to the development of hard coal deposits was performed with the participation of experts who were selected based on their competencies encompassing all aspects of the analysed problem. They represented the following fields of science: geology, mining, urban planning, spatial planning, sociology, management and environmental engineering.

Based on specially prepared questionnaires, the experts compared all elements of particular levels pairwise in relation to each element of the higher level. The questionnaire which was used to evaluate the possibilities for developing deposits from closed-down mines is presented in Table 3. While making comparisons, the experts decided which factor is more important in achieving particular criteria or the main goal. As a result, by using the AHP methodology, as was presented in this article, values were obtained that pertained to the weights (priorities) of particular factors in terms of their importance in achieving the ultimate goal, i.e. an evaluation of the possibility of conflict related to the development of deposits.

The obtained evaluations are presented in the form of local and global weights in Fig. 2 in order to better illustrate the relations between the elements of the hierarchical structure. 
A questionnaire designed to compare variables pairwise with regard to the possibility of conflict in relation to the development of hard coal deposits (based on questionnaire survey)

Porównywanie zmiennych parami ze względu na możliwość wystąpienia konfliktu w kontekście zagospodarowania złóż węgla kamiennego (na podst. badań ankietowych)

Which of the compared variables, and to what extent, is more important as regards the impact it might have on the possibility of conflict over the development of hard coal deposits? Please compare the variables pairwise

(determine the dominance of one variable over another) according to the scale and mark the appropriate box.

Rating scale: 1 - equally important, 3 - somewhat more important, 5 - much more important, 7 - very much more important, 9 - absolutely more important (than the other variable)

\begin{tabular}{|c|c|c|c|c|c|c|c|c|c|c|}
\hline & $\begin{array}{c}\text { absolutely } \\
\text { more } \\
\text { important }\end{array}$ & $\begin{array}{c}\text { very } \\
\text { much } \\
\text { more } \\
\text { important }\end{array}$ & $\begin{array}{c}\text { much } \\
\text { more } \\
\text { important }\end{array}$ & $\begin{array}{c}\text { somewhat } \\
\text { more } \\
\text { important }\end{array}$ & $\begin{array}{c}\text { equally } \\
\text { important }\end{array}$ & $\begin{array}{c}\text { somewhat } \\
\text { more } \\
\text { important }\end{array}$ & $\begin{array}{c}\text { much } \\
\text { more } \\
\text { important }\end{array}$ & $\begin{array}{c}\text { very } \\
\text { much } \\
\text { more } \\
\text { important }\end{array}$ & $\begin{array}{c}\text { absolutely } \\
\text { more } \\
\text { important }\end{array}$ & $C I=0.06$ \\
\hline Variable & 9 & 7 & 5 & 3 & 1 & 3 & 5 & 7 & 9 & Variable \\
\hline $\begin{array}{l}\text { Spatial \& } \\
\text { demographic }\end{array}$ & & & & X & & & & & & Economic \\
\hline $\begin{array}{l}\text { Spatial \& } \\
\text { demographic }\end{array}$ & & & & & $\mathrm{X}$ & & & & & Social \\
\hline $\begin{array}{l}\text { Spatial \& } \\
\text { demographic }\end{array}$ & & & & & $\mathrm{X}$ & & & & & $\begin{array}{c}\text { Environ- } \\
\text { mental }\end{array}$ \\
\hline Economic & & & & & & $\mathrm{X}$ & & & & Social \\
\hline Economic & & & & & X & & & & & $\begin{array}{c}\text { Environ- } \\
\text { mental }\end{array}$ \\
\hline Social & & & & & $X$ & & & & & $\begin{array}{c}\text { Environ- } \\
\text { mental }\end{array}$ \\
\hline
\end{tabular}

\subsection{A ranking of hard coal deposits with regard to the possibility of conflict}

As a result of the calculations, resultant vectors were obtained for 15 hard coal deposits undergoing evaluation (Table 4). The values of these vectors were used to generate a ranking of hard coal deposits in relation to the possibility of conflict that could occur if they were considered for development. In this analysis the resultant vectors were multiplied by 100 for better readability. Values within a range of $0-100$ were obtained. The higher a vector value, the greater the possibility of conflict.

Final calculations showed that, in the final ranking and after taking into account all the model's elements undergoing evaluation, the Oświęcim-Polanka deposit has the highest 
Final resultant vectors for the evaluated deposits

Końcowe wektory wynikowe ocenianych złóż

\begin{tabular}{|c|l|c||}
\hline \hline Item No. & \multicolumn{1}{|c|}{ Evaluated deposit } & Resultant vector \\
\hline \hline 1. & Oświęcim-Polanka & 10.33 \\
\hline 2. & Dębieńsko & 8.86 \\
\hline 3. & Studzienice & 7.88 \\
\hline 4. & Zator & 7.10 \\
\hline 5. & Żory & 6.87 \\
\hline 6. & Międzyrzecze & 6.84 \\
\hline 7. & Palowice & 6.73 \\
\hline 8. & Morcinek & 6.38 \\
\hline 9. & Ćwiklice & 6.38 \\
\hline 10. & Siersza & 6.35 \\
\hline 11. & Wisła I-II & 6.26 \\
\hline 12. & Za rowem bełckim & 6.16 \\
\hline 13. & Niwka-Modrzejów & 5.16 \\
\hline 14. & Jan Kanty & 5.07 \\
\hline 15. & Polanka & 3.52 \\
\hline
\end{tabular}

resultant vector value (10.33) and thus has the greatest potential for conflict. The next deposits in the ranking were: Dębieńsko (8.86) and Studzienice (7.88). Deposits which are the least probable to cause conflict are: Polanka (3.52), Jan Kanty (5.07) and Niwka-Modrzejów (5.16).

When analysing the impact of particular factors on the final ranking, one must first consider the results obtained for the main groups of criteria at level 2 . The weights generated for these criteria are shown in Fig. 3. Economic and social criteria are the most important in achieving the ultimate goal, i.e. selecting deposits with the greatest potential for conflict out of the four selected groups of criteria. For these groups of criteria weights: 0.305 and 0.289 were determined, respectively. Environmental (0.148) as well as spatial and demographic $(0.258)$ factors are the least important.

As for the factors from level 3 of the model, the most important, in terms of their impact on the ranking of deposits, are first of all: the commune's income (0.131) and local media activity, including Internet portals $(0.120)$, and then landscape parks and Natura 2000 sites $(0.114)$, as well as the unemployment rate $(0.112)$. The following subcriteria: the area of a deposit (0.032) and other forms of site and feature conservation (0.033) (Fig. 4) are the least important (i.e. expressed by the lowest values of weights). 


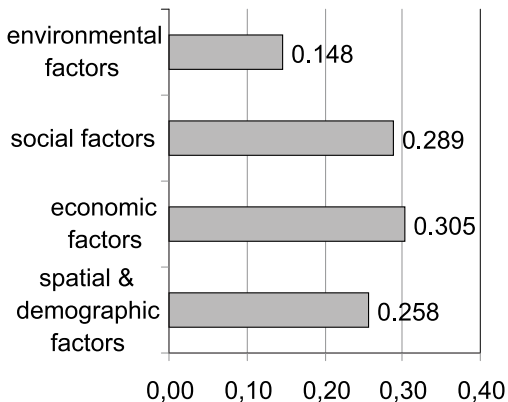

Fig. 3. Weights of the main groups of criteria at level II

Rys. 3. Wagi głównych grup kryteriów poziomu II

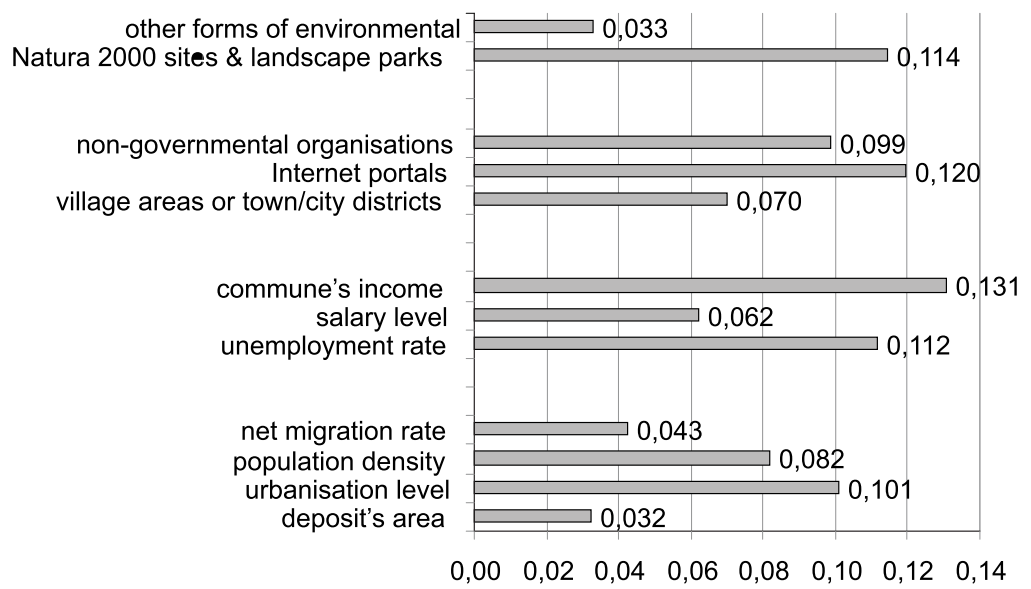

Fig. 4. Global weights of subcriteria at level III

Rys. 4. Wagi globalne subkryteriów poziomu III

It should be noted that the highest global weights of level 3 were obtained for different groups of criteria at level 2, both the most preferred groups, such as of economic and social criteria, and the least preferred group, i.e. environmental criteria. Partial evaluations of the subcriteria show that the preference for economic and social criteria groups, without prior calculations, would be a wrong assumption.

A highly varied impact of particular criteria on a potential conflict related to the development of deposits is a characteristic feature of this ranking (Fig. 5). The largest limitations concerning the group of spatial and demographic criteria may be encountered with respect to the following deposits: Za rowem bełckim, Morcinek and Oświęcim-Polanka. Economic aspects are the most important in the case of the Ćwiklice, Studzienice and Jan Kanty deposits. Social criteria constitute the biggest potential limitation for the development of the Dębieńsko, Studzienice and Żory deposits. As for deposits: Oświęcim-Polanka, Zator and Międzyrzecze, environmental criteria constitute the biggest threat. 


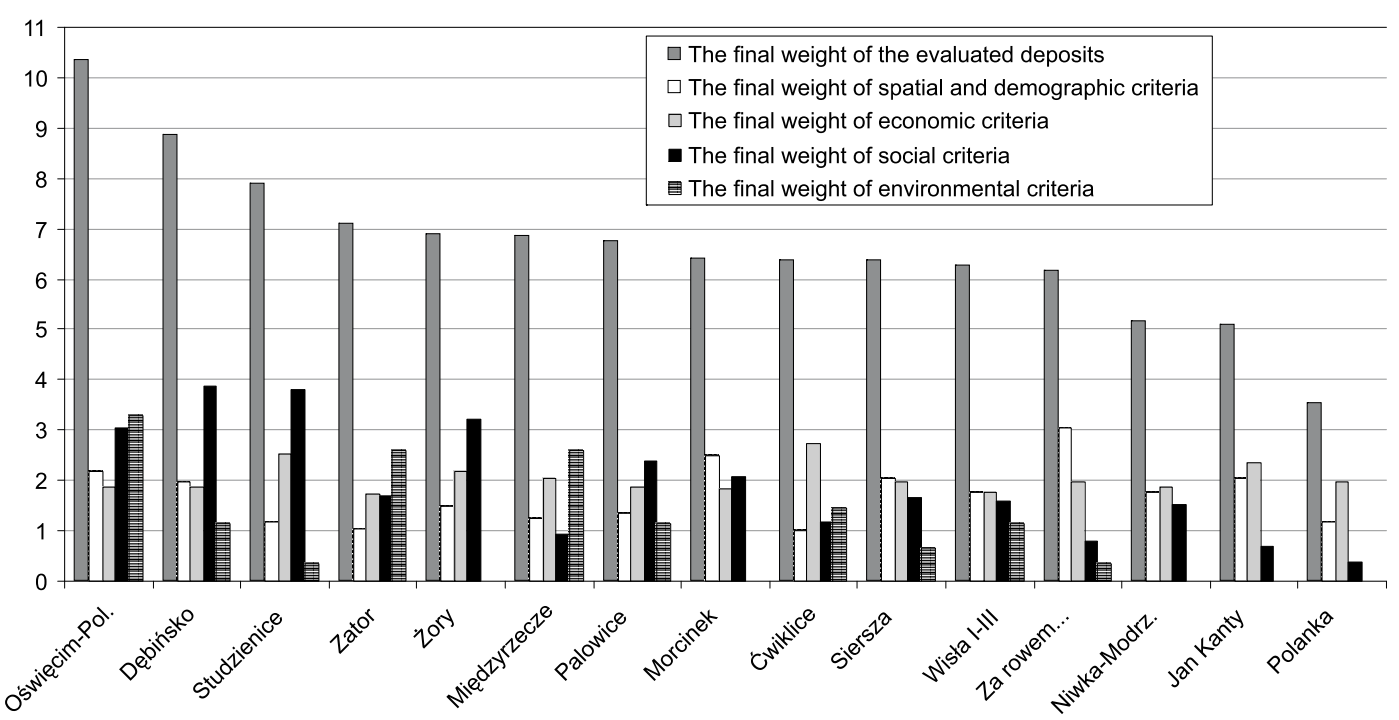

Fig. 5. Ranking of deposits with regard to partial evaluations obtained for particular criteria

Rys. 5. Ranking złóż ze względu na cząstkowe oceny dla poszczególnych grup kryteriów

The Oświęcim-Polanka deposit was finally evaluated as having the greatest potential for conflict in the context of summary evaluations of main criteria groups, which was undoubtedly due to social and environmental factors, whereas spatial and demographic criteria contributed to a lesser extent. The economic aspects turned out not to be so much important. If only economic criteria were taken into account, the Oświęcim-Polanka deposit would be the $12^{\text {th }}$ in the ranking, whereas if only spatial and demographic as well as social aspects were considered - it would be the $3^{\text {rd }}-4^{\text {th }}$, and if only environmental aspects were analysed - it would be the $1^{\text {st }}$ among the 15 deposits that were evaluated.

The area of Polanka was ranked as having the lowest potential for conflict because of the lack of environmental limitations and the lowest (out of all the areas) importance of social aspects. Also, spatial and demographic criteria were of relatively low importance (among the last in the ranking), whereas the economic aspect was of average importance, i.e. it was at a level comparable to other deposits. It should be remembered that the authors separated the Polanka area from the Oświęcim-Polanka deposit for the purposes of this analysis. This is clear evidence that, in most cases, it is possible to separate areas for mineral extraction with a relatively low potential for conflict.

\section{Summary and conclusion}

As regards the development of new deposits, local social determinants have been playing an increasing role. Such determinants also encompass the activities of local authorities, 
non-governmental organisations and inhabitants as well as other entities which operate in a given area (stakeholders of a mining company).

The hard coal mining sector (not only in Poland) must allow for the possibility of protests at every stage of its operations, but the phase when the first licence is obtained should be deemed the most prone to conflict. Whether it is the reopening of an abandoned deposit site or a completely new mining area does not seem to play a key role here.

As the conducted modelling research showed, the mathematical, multi-criteria decision-making AHP method can be successfully used to make a preliminary evaluation of the possibility of social conflict related to environmental issues. It allows for creating a ranking of selected deposits in terms of the risk of protests from the mining stakeholders.

A given calculated parameter value does not guarantee that there will be no conflicts or that a conflict will definitely occur. It should also be remembered that, in practice, merely one factor (one criterion of analysis), or even a specific activity of individuals, may play a decisive role.

Based on the analysis that was carried out using the multi-criteria AHP method, the areas which can be regarded as the least prone to conflict are the Niwka-Modrzejów and Jan Kanty deposits, and especially the Polanka deposit which was separated by the authors from the Oświęcim-Polanka deposit for the purposes of this analysis (Fig. 1). However, Oświęcim-Polanka taken as a whole is a deposit which is particularly prone to conflict. Dębieńsko or Studzienice, which are next, are characterised by a much lower risk of social and environmental conflict (Table 4).

From the state's or an individual investor's point of view, social determinants are certainly not decisive. The authors would like to note that also geological as well as technical and economic factors can be included in a multi-criteria analysis in order to obtain a complete, though rough, picture of the possibility of developing given areas for mining with emphasis on deposits with the best relative prospects. With the exception of isolated cases, such methods have not been commonly used.

As the example of the Oświęcim-Polanka deposit shows, an analysis of this kind also allows for comparing selected parts of the same area and thus facilitates the choice of optimal variant of its development.

Further work on adjusting the AHP method to the specificity of mining is recommended so that it can become a useful tool in a decision-making process for different kinds of national and local institutions as well as entities in the raw material sectors.

\section{REFERENCES}

B a d e r a J., 2010 - Social conflicts on the environmental background related to development of mineral deposits in Poland. Mineral Resources Management (Gospodarka Surowcami Mineralnymi) vol. 26, no. 1, pp. $105-125$. B ascetin A., 2007 - A decision support system using analytical hierarchy process (AHP) for the optimal environmental reclamation of an open-pit mine. Environmental Geology vol. 52, no. 4, pp. 663-672.

Byrska-Rąpała A., 2008 - Geoethics and social responsibility of energy raw materials industry. Mineral Resources Management (Gospodarka Surowcami Mineralnymi) vol. 24, no. 4/4, pp. 41-52. 
Cragg et al. 1995 - Cragg W., P e ar s on D., C o o n e y J., 1995 - Ethics, surface mining and the environment. Resources Policy vol. 21, no. 4, pp. 229-235.

Esteves A.M., 2008 - Mining and social development: Refocusing community investment using multi-criteria decision analysis. Resources Policy vol. 33, no. 1, pp. 39-47.

Esteves A.M., Barclay M.-A., 2011 - New Approaches to Evaluating the Performance of Corporate-Community Partnerships: A Case Study from the Minerals Sector. Journal of Business Ethics vol. 103, no. 2, pp. $189-202$

Frączek P., 2011 - Dealing with locational conflicts in the energy sector. Energy Policy Journal (Polityka Energetyczna) vol. 14, no. 2, pp. 65-78.

Hebestreit et al. 2011 - Hebestreit C., Kulczycka J., Wirth H., ed., 2011 - Sustainable production and consumption of mineral resources. Publ. of MEERI PAS, Kraków.

Humphreys D., 2000 - A business perspective on community relations in mining. Resources Policy vol. 26, no. 3, pp. 127-131.

J en a P.K., 1992 - Development and conservation of mineral-resources. Transactions of the Indian Institute of Metals vol. 45 , no. 2, pp. 79-88.

Mossakowska T., Wasilewski M., 2011 - Is the Polish coal mining industry ready to accept a new CSR paradigm? Mining Review (Przegląd Górniczy) vol. 66, no. 10, pp. 47-59.

Nieć M., 2008 - Centenary of the idea of mineral deposits protection. Mineral Resources Management (Gospodarka Surowcami Mineralnymi) vol. 24, no. 2/2, pp. 47-51.

Niemczyk P., 2011 - Pro-ecological technologies and sustainable development of hard coal mines. Mining Review (Przegląd Górniczy) vol. 66, no. 10, 22-25.

Poros M., Sobczyk W., 2013 - Rewitalizacja terenu pogórniczego po kopalni surowców skalnych na przykładzie kamieniołomu Wietrznia w Kielcach. Annual Set The Environment Protection, Vol. 15, Middle Pomeranian Scientific Society of the Environment Protection, Koszalin, s. 2369-2380.

Prno J., Slocombe D.S., 2012 - Exploring the origins of 'social license to operate' in the mining sector: Perspectives from governance and sustainability theories Resources Policy vol. 37, no. 3, pp. 346-357.

R a d w a n e k-B ąk B., 2007 - The concept of multi-criteria mineral resources protection. Environmental Geology vol. 52 , no. 1 , pp. 137-145.

Radwa nek-B ąk B., Ni eć M., 2011 - The protection of mineral resources - a way of a difficult compromise. Mining Review (Przegląd Górniczy) vol. 66, no. 10, pp. 7-15.

R a ma n i R.V., S w e i g ard R.J., 1984 - Impacts of land-use planning on mineral resources. Mining Engineering vo. 36 , no. 4 , pp. 362-369.

S a a ty T.L., 1980 - The Analytic Hierarchy Process. McGraw-Hill, New York.

Sobczyk et al. 2011 - Sobczyk E.J., Wota A., Krężołek S., 2011 - The application of mathematical multi-criteria methods for choosing the optimal alternative for hard coal acquisition. Mineral Resources Management (Gospodarka Surowcami Mineralnymi) vol. 27, no. 3, pp. 51-68.

Sobczyk E.J., 2008 - Analytic Hierarchy Process (AHP) and Multivariate Statistical Analysis (MSA) [In:] Evaluating mining difficulties in coal mines. $21^{\text {st }}$ World Mining Congress - New challenges and visions for Mining, Kraków. Taylor \& Francis Group, A Balkema Book, London, pp. 329-345.

S obczyk W., 2007 - Environmental nuisances of hard coal mining activity in respondents' opinion - Survey report. Mining and Geoengineering (Górnictwo i Geoinżynieria) vol. 31, no. 3/1, pp. 497-506.

Uberman R., Ostręga A., 2008 - Applying the Analytic Hierarchy Process for the valorisation (ranking) of the Polish lignite deposit. Mineral Resources Management (Gospodarka Surowcami Mineralnymi) vol. 24 , no. $2 / 4$, pp. $73-95$. 


\section{PROBLEM ZAGOSPODAROWANIA PERSPEKTYWICZNYCH ZLÓŻ WEGLA KAMIENNEGO Z PUNKTU WIDZENIA MOŻLIWYCH KONFLIKTÓW SPOŁECZNO- ŚRODOWISKOWYCH Z WYKORZYSTANIEM METODY AHP}

Słowa kluczowe

\section{Streszczenie}

W ostatnich latach odnotowano w Polsce i innych krajach europejskich liczne konflikty związane z zagospodarowaniem nowych złóż surowców mineralnych lub wznowieniem wydobycia ze złóż zaniechanych. Artykuł prezentuje możliwości przewidywania, które ze złóż są relatywnie mało konfliktowe pod względem lokalnych uwarunkowań społecznych. Jak wykazują przeprowadzone badania, w tym celu z powodzeniem może być stosowana wielokryterialna analiza decyzyjna metodą AHP (Analytic Hierarchy Process). Pozwala ona na stworzenie wstępnego rankingu wytypowanych złóż pod względem ryzyka sprzeciwu lokalnych interesariuszy górnictwa. Jak pokazuje przykład złoża Oświęcim-Polanka, tego typu analiza pozwala także na porównanie wytypowanych części jednego obszaru, co pozwala na wybór optymalnego (w sensie przestrzennym) wariantu jego zagospodarowania. Sugeruje się dalsze prace nad dostosowaniem metody AHP do specyfiki górnictwa tak, aby stała się ona użytecznym narzędziem w procesie decyzyjnym dla instytucji publicznych (optymalizacja decyzji) oraz spółek górniczych (minimalizacja ryzyka inwestycyjnego).

THE PROBLEM OF DEVELOPING PROSPECTIVE HARD COAL DEPOSITS FROM THE POINT OF VIEW OF SOCIAL AND ENVIRONMENTAL CONFLICTS WITH THE USE OF AHP METHOD

$$
\text { Key words }
$$

Mining, social determinants, multi-criteria analysis, Upper Silesia

\section{Abstract}

In the recent years numerous socio-environmental conflicts have been reported in Poland and other European countries in relation to the development of new or reopening of abandoned mineral deposits. This paper examines possibilities of predicting which of the specified deposits are relatively less contentious with regard to the local social determinants. As the conducted research showed, the multi-criteria decision-making AHP (Analytic Hierarchy Process) method can be successfully used to fulfill this goal. It allows for creating a preliminary ranking of selected deposits in terms of the risk of objections from the local mining stakeholders. As the example of the Oświęcim-Polanka deposit shows, an analysis of this kind also allows for comparing selected parts of the same area and thus facilitates the choice of optimal variant of its development in space. Further work on adjusting the AHP method to the specificity of mining is recommended so that it can become a useful tool in a decision-making process for public institutions (to make optimal decisions) as well as mining companies (to minimise investment risk). 